\title{
Response of white-tailed deer foods to discing in a semiarid habitat
}

\author{
TIMOTHY E. FULBRIGHT
}

Author is professor and chair, Department of Animal and Wildlife Sciences and researcher, Caesar Kleberg Wildlife Research Institute, Texas A\&M University-Kingsville, Kingsville, Tex. 78363.

\begin{abstract}
Discing strips of rangeland to increase wildlife foods is a common management practice. I tested the hypotheses (1) annual discing results in greater canopy cover of annual forbs preferred by white-tailed deer (Odocoileus virginianus Raf.) than discing at less frequent intervals of time, (2) frequent discing reduces the abundance of preferred perennial forbs, and (3) discing only once results in greater total canopy cover of annual and perennial forbs preferred by deer. The experimental design was a split-plot with soil series (Ramadero loam or Delfina fine sandy loam) as main plots and discing treatment in October as subplots. Discing treatments were (1) no treatment (control); (2) discing once in 1990; (3) discing once in 1994; (4) discing in 1990 and 1994; (5) discing in 1990, 1992, and 1994; and (6) discing annually from 1990-1994. Discing increased canopy cover of annuals preferred by white-tailed deer and increased canopy cover of unpalatable forbs, but decreased preferred perennials. Canopy cover of forbs eaten, but not preferred by deer, increased following discing. Based on these results, soil disturbance by discing is not recommended as a habitat improvement practice in the semiarid western Rio Grande Plains of Texas if the objective of management is to increase canopy cover of forbs preferred by white-tailed deer.
\end{abstract}

Key Words: forbs, habitat improvement, Odocoileus virginianus Raf., patches, plant succession, semi-arid environments

Discing strips of rangeland is commonly recommended by wildlife specialists as a management tool to increase the abundance of early-successional annual forbs preferred by whitetailed deer (Odocoileus viginianus Raf.) and to provide herbage and seeds for northern bobwhites (Colinus virginianus Merr.) (Arnold and Drawe 1979, Webb and Guthery 1983, Nurdin and Fulbright 1988). In Florida, discing promoted a variety of valuable food plants for northern bobwhites

Research was funded by the Caesar Kleberg Foundation. El Tecomate Ranch Partnership provided land and heavy equipment. Dr. G. Schwarz and the late Dr. $\mathrm{S}$. Beasom provided the initial ideas and encouragement for this study. I thank $\mathrm{N}$. Beals, J. Bonner, L. Brothers, J. Duffy, M. Hehman, G. Krueger, H. Olson, S. Patten, and S. Sickenius for their assistance and S. Demarais and D. Hewitt for reviewing early drafts of the manuscript. R. Bingham assisted in statistical analyses. This is CKWRI manuscript number 97-102.

Manuscript accepted 27 Aug. 1998.

\section{Resumen}

El rastreo de franjas de pastizal para incrementar los alimentos de la fauna silvestre es una práctica común de manejo. Probé las siguientes hipótesis 1) el rastreo anual resulta en una mayor cobertura de la copa de las hierbas anuales preferidas por el venado cola blanca (Odocoileus virginianus. Raf.) que rasterando a intervalos menos frecuentes, 2) el rastreo frecuente reduce la abundancia de hierbas perennes preferidas y 3) rastreando solo una vez resulta en una cobertura total mayor de hierbas anuales $y$ perenes preferidas por el venado. El diseño experimental fue el de parcelas divididas, la parcela principal fue series de suelo (Ramadero y Delfina) y la subparcela fue el tratamiento de rastreo en Octubre. Los tratamientos de rastreo fueron: (1) no rastreo (control); (2) rastreo una sola vez en 1990; (3) rastreo una sola vez en 1994; (4) rastreo en 1990 y 1994; (5) rastreo en 1990, 1992 y 1994 y (6) rastreo anual de 1990 a 1994. El rastreo incrementó la cobertura de la copa de las especies anuales preferidas por el venado cola blanca e incrementó la cobertura de copa de hierbas no preferidas pero también redujó las especies perennes preferidas. La cobertura de la copa de las hierbas consumidas pero no preferidas por el venado cola blanca se incrementó después del rastreo. Basado en estos resultados se puede concluir que si el objetivo es incrementar la cobertura de las hierbas preferidas por el venado cola blanca, el disturbio del suelo por el rastreo no es recomendado como una práctica de mejoramiento del hábitat en las regiones semiáridas del oeste de las planicies del Río Grande.

(Landers and Mueller 1986:21-23). Discing in northwest Texas promoted several plant species important for wildlife, but forb production and density on the disced strips were relatively low (Webb and Guthery 1983). Discing sites dominated by whitebrush [Aloysia gratissima (Gill. \& Hook.) Trancoso] did not consistently increase forbs eaten by white-tailed deer in the western Rio Grande Plains of Texas (Bozzo et al. 1992).

There is little information in the literature regarding the frequency of discing needed to maintain increased abundance of wildlife food plants. Jones et al. (1993) compared discing once with discing 2 years in a row and reported that discing 2 years in a row resulted in greater canopy cover of northern bobwhite food plants in the South Carolina Piedmont. In the Coastal Plain of South Carolina, neither treatment increased 
abundance of northern bobwhite food plants.

Frequent, intense disturbances result in patches being occupied only by quickly maturing annuals, whereas infrequent disturbances allow establishment of slower-growing perennials (Connell 1978). Perennial forb species are more important in white-tailed deer diets than annuals (Scifres 1980). Frequent discing is a desirable habitat management practice for white-tailed deer if the practice consistently results in increased abundance of perennial and annual forbs preferred by deer. Conversely, frequent discing is undesirable if the practice reduces preferred perennial forbs.

My objective was to determine the frequency of discing that produces the greatest canopy cover of herbaceous plants preferred by white-tailed deer. I tested the hypotheses that (1) annual discing results in greater canopy cover of annual forbs preferred by white-tailed deer than discing at less frequent intervals of time; (2) frequent discing reduces the abundance of perennial forbs preferred by deer; and (3) discing only once allows reestablishment of perennial forbs, resulting in greater total canopy cover of annual and perennial forbs preferred by deer than annual discing or no discing.

\section{Materials and Methods}

\section{Study Area}

Research was conducted on the El Tecomate Ranch (98 $50^{\circ}$ longitude, $26^{\circ} 45^{\prime}$ latitude) in Starr County, Tex., $40 \mathrm{~km}$ north of Rio Grande City. Dominant vegetation on the study area was a honey mesquite (Prosopis glandulosa Torr.)-mixed brush community (Thompson et al. 1972). Average annual rainfall was $43.9 \mathrm{~cm}$ (1931-1962). The average annual maximum temperature was $30.6^{\circ} \mathrm{C}$ and the average annual minimum was $16.3^{\circ} \mathrm{C}$. Soils on study sites were Ramadero loam or Delmita fine sandy loam. Rainfall within the study area was monitored with an electronic rain gauge.

The 809-ha study area was not grazed by livestock during 1990, 1991, and in 1995. Cattle stocking rates (steers) were $8.4,19.3$, and $17.8 \mathrm{ha} /$ animal unit during 1992, 1993, and 1994, respectively. Cattle grazed from late-April to mid-
August, late April to October, and July to August during 1992, 1993, and 1994, respectively. An average of $9 \pm 0.4$ deer $/ \mathrm{km}(\bar{x} \pm \mathrm{SE}, n=9)$ were counted during fall and winter from a helicopter during 1990-1995. DeYoung (1985) found that 33 to $67 \%$ of the deer actually present are counted during helicopter counts in south Texas.

Grazing by cattle and white-tailed deer possibly differentially affected herbaceous plant species composition among discing treatments. Study plots were not fenced to exclude herbivores and grazing effects were not documented. Effects of cattle grazing on treatments were minimized because (1) cattle were not present during 1990, 1991, and 1995; (2) cattle were grazed for only 2-6 months during 1992-94; (3) cattle numbers were low relative to the stocking rates normally used in the area; and (4) cattle were removed in August, except during 1993. Summers are generally dry in Starr County, whereas the highest rainfall months are September and October. Thus, the study sites were free of cattle during the highest rainfall period and for 6 months thereafter.

Table 1. Scientific and common names of herbaceous plants encountered on control and disced plots during 1991-1995, Starr County, Texas, in 3 categories based on data from Everitt and Drawe (1974), Arnold and Drawe (1979), and Hehman (1995).

\begin{tabular}{|c|c|c|}
\hline Plant category and scientific name & Common name & $\begin{array}{l}\text { Season of } \\
\text { Growth }\end{array}$ \\
\hline \multicolumn{3}{|l|}{ Preferred Annuals } \\
\hline Aphanostephus ramosissimus DC. & Plains lazydaisy & Warm \\
\hline Aphanostephus skirrhobasis (DC.) Trel. & Kidder lazydaisy & Warm \\
\hline Euohorbia prostata Ait. & Prostrate euphorb & Warm \\
\hline Gaura brachycarpa Small & Plains gaura & Cool \\
\hline \multicolumn{3}{|l|}{ Preferred Perennials } \\
\hline Acleisanthes obtusa (Choisy) Standl. & Berlandier trumpets & Warm \\
\hline Ambrosia cumanensis Kunth in H.B.K. & Western ragweed & Warm \\
\hline Commelina erecta $\mathrm{L}$. & Narrowleaf dayflower & Warm \\
\hline Cynanchum barbigerum (Scheele) Shinners & Bearded swallow-wort & Warm \\
\hline Lantana macropoda Torr. & Veinyleaf lantana & Warm \\
\hline Menodora heterophylla Moric. & Low menodora & Warm \\
\hline Parthenium confertum Gray & Lyreleaf parthenium & Warm \\
\hline Physalis cinerascens (Dun.) A. S. Hitchc. & Beach groundcherry & Warm \\
\hline Ratibida columnifera (Nutt.) Woot. \& Standl. & $\begin{array}{l}\text { Upright prairie } \\
\text { cone flower }\end{array}$ & Warm \\
\hline Solanum triquetrum Cav. & Texas nightshade & Warm \\
\hline Trixis inula Cranz. & Mexican trixis & Cool \\
\hline Wedelia hispida H.B.K. & Orange zexmenia & Warm \\
\hline Xanthisma texanum DC. & Sleepy daisy & Warm \\
\hline \multicolumn{3}{|l|}{ Unpalatable species } \\
\hline Palafoxia texana DC. & Texas palafoxia & Warm \\
\hline Salsola iberica Senn. \& Pau & Russian thistle & Warm \\
\hline Verbesina enceliodes (Cay.) Benth. \& Hook. ex Gray & Cowpen daisy & Warm \\
\hline
\end{tabular}




\section{Experimental Design and Vegetation Sampling}

Six, 10-m X 40-m plots separated by 10-m-wide buffers were delineated within each of 4 blocks on Ramadero loam and 4 blocks on Delmita fine sandy loam. Six treatments were randomly assigned to the plots within each of the 4 blocks within each soil series. Blocks within a soil series were within $0.5 \mathrm{~km}$ of each other and soil series were $<1 \mathrm{~km}$ apart. Treatments were (1) no treatment (control); (2) discing once in 1990; (3) discing once in 1994; (4) discing in 1990 and 1994; (5) discing in 1990, 1992, and 1994; and (6) discing annually during 1990-1994. Discing was conducted each October during 1990-1994. I selected October based on results of unpublished data that indicated a greater response of forbs to fall discing than to spring or summer discing. Treatment plots were disced with a heavy disc with 2 gangs of $107-\mathrm{cm}$ diameter blades. The disc was pulled by a crawler tractor (Caterpillar D-7) and 2 passes were made within each plot on each treatment date. Mean depth of disc penetration in Ramadero loams ranged from $14 \pm 0.8(\mathrm{n}=4) \mathrm{cm}$ in 1993 to $19 \pm$ $0.3 \mathrm{~cm}$ in 1994. In Delmita fine sandy loams, mean depth of disc penetration ranged from $12 \pm 0.2 \mathrm{~cm}$ in 1990 to $18 \pm$ $0.5 \mathrm{~cm}$ in 1994 .

Canopy cover and frequency of herbaceous species were ocularly estimated during March 1991-1995 within twentyfive, $20 \times 50-\mathrm{cm}$ quadrats placed in a restricted-random fashion within each soil series, treatment, and replication combination. Sampling was conducted during March because I observed that the peak abundance of cool-season forbs in the study area generally occurs in March. Herbaceous plant species were categorized as "preferred annuals", "preferred perennials", "preferred annuals and perennials", "unpalatable" species (Table 1), and "other" species. Preferred annual and perennial species were those ranked in the top 40 species found in deer diets $<25 \mathrm{~km}$ from El Tecomate Ranch by Arnold and Drawe (1979). "Other" species were those not ranked in the top 40 species found in deer diets but recorded as present in deer diets on El Tecomate Ranch (Hehman 1995) and $<25 \mathrm{~km}$ from El Tecomate Ranch by Everitt and Drawe (1974) and Arnold and Drawe (1979). "Unpalatable" species were not encountered in deer diets on El Tecomate Ranch (Hehman 1995) or $<25 \mathrm{~km}$ from El Tecomate Ranch by Arnold and Drawe (1979).

\section{Statistical Analyses}

I used analysis of variance (PROC GLM; SAS Inst. Inc. 1988) for a splitplot experimental design with soil series as main plots and discing treatment as subplots to test for significant $(\mathrm{P}<0.05)$ soil series and discing treatment main effects and interactions. The timing of discing, with certain plots disced once and others at periodic intervals of time, resulted in different treatment combinations in different years. Two treatments, control and disced once in 1990, were compared in 1991; 3 treatments (control, disced once in 1990, and annual discing) were compared in 1992; 4 treatments (control, disced once in 1990, disced in 1990 and 1992, and annual discing) were compared in 1993 and 1994; and 6 treatments (control; disced once in 1990, disced once in 1994, disced in 1990 and 1994; disced in 1990, 1992, and 1994; and annual discing) were compared in 1995. PROC GLM was used because sample sizes were unequal. In March 1991 there were 8 control plots (2 soil series $\mathrm{x} 4$ blocks) and 32 plots disced in October 1990 (2 soil series x 4 blocks x 4 plots); in March 1992 there were 8 control plots, 8 plots disced in October 1990 and 1991 ( 2 soil series x 4 blocks), and 24 plots disced in October 1990 (2 soil series x 4 blocks x 3 plots). Separate analyses were conducted for each year of sampling and for each preference class (preferred annual forbs, preferred perennial forbs, preferred annuals and perennials combined, other herbaceous plant species, and unpalatable forbs) except for 1993 and 1994. In analyses, arcsin transformed canopy cover (\%) was the dependent variable. When the soil series $\mathrm{X}$ discing treatment interaction was significant $(\mathrm{P} \leq 0.05)$, I conducted a separate analysis of variance for a randomized, complete-block design for each soil series with arcsin transformed canopy cover (\%) as the dependent variable and discing treatment as the independent variable to allow means separation. I used the Tukey-Kramer option in SAS for comparing the least squares means $(\mathrm{P} \leq 0.05)$ for arcsin transformed percent canopy cover.

Repeated measures analyses were conducted for 1993 and 1994 data with year as the repeated measure since sample sizes among treatments were equal between sampling dates (Cody and Smith 1991). When the discing treatment $X$ sampling date interaction was significant $(\mathrm{P} \leq 0.05)$, I conducted a separate analysis of variance for each sampling date (1993 or 1994) as previously described.

Certain plant species colonize large patches more readily than smaller patches Glenn and Collins 1992, Arnthórsdóttir 1994). However, there is little reason to expect that our results would differ among patch sizes normally created in rangeland discing. Glenn and Collins (1992) compared colonization on regional versus local scales, whereas patches compared by Arnthórsdóttir (1994) were $\leq 200 \mathrm{~cm}^{2}$.

\section{Results}

Discing during October generally increased $(\mathrm{P} \leq 0.05)$ canopy cover of preferred annuals the following March compared to controls (Table 2). Exceptions occurred in March 1992 when canopy cover on disced plots and controls did not differ significantly $(\mathrm{P}>$ 0.05). Also, the soil series $X$ discing treatment interaction was significant $(\mathrm{P}$ $=0.001$ ) in March 1995. No preferred annuals were present on disced treatments or controls on Ramadero loam soils. Canopy cover of preferred annuals on Delfina fine sandy loams ranged from $1 \pm 1$ to $3 \pm 1 \%(\bar{x} \pm \mathrm{SE})$ compared to $<1 \pm<1 \%$ on controls. On Delfina fine sandy loam soils in March 1995, canopy cover of annuals was greater $(\mathrm{P} \leq 0.05)$ on disced plots than controls, but no significant $(\mathrm{P} \leq 0.05)$ differences in canopy cover of annuals existed among the discing treatments themselves.

Canopy cover of preferred perennials was generally greater $(\mathrm{P}<0.05)$ on controls than on disced plots. The soil series $\mathrm{X}$ discing treatment interaction was significant $(P=0.007)$ in March 1993-1994 for preferred perennial canopy cover. Preferred perennials were virtually absent from Ramadero soils during March 1993-1994, with canopy cover ranging from $<1 \pm<1 \%$ on annually disced plots to $1 \pm<1 \%$ on controls and not differing significantly $(\mathrm{P}>0.05)$ among treatments. Control plots sup- 
Table 2. Mean canopy cover (\%) of herbaceous plants during March 1991-1995 on Delfina fine sandy loam and Ramadero loam in plots not disced (control) or disced during October 1990; 1994; 1992 and 1994; 1990, 1992, and 1994; or 1990-1994; Starr County, Tex.

\begin{tabular}{|c|c|c|c|c|c|c|c|c|c|c|c|}
\hline \multirow{3}{*}{ Treatment } & \multicolumn{11}{|c|}{ Plant Class } \\
\hline & \multirow[b]{2}{*}{$\mathrm{n}$} & \multicolumn{2}{|c|}{$\begin{array}{l}\text { Preferred } \\
\text { annuals }\end{array}$} & \multicolumn{2}{|c|}{$\begin{array}{l}\text { Preferred } \\
\text { perennials }\end{array}$} & \multicolumn{2}{|c|}{$\begin{array}{c}\text { Preferred } \\
\text { annuals and } \\
\text { perennials }\end{array}$} & \multicolumn{2}{|c|}{$\begin{array}{l}\text { Other species } \\
\text { eaten by deer }\end{array}$} & \multicolumn{2}{|c|}{$\begin{array}{l}\text { Unpalatable } \\
\text { species }\end{array}$} \\
\hline & & $\bar{x}$ & SE & $\bar{x}$ & SE & $\frac{p}{x}$ & SE & $\bar{x}$ & SE & $\bar{x}$ & SE \\
\hline \multicolumn{12}{|c|}{ 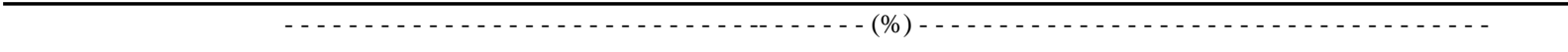 } \\
\hline \multicolumn{12}{|c|}{1991} \\
\hline Control & 8 & $2 b^{1,2}$ & I & $4 a$ & 1 & $6 b^{2}$ & 1 & $21 b$ & 4 & $<\mathrm{lb}$ & $<1$ \\
\hline Disc-90 & 32 & $13 \mathrm{a}$ & 1 & $\mathrm{lb}$ & $<\mathrm{I}$ & $14 \mathrm{a}$ & 1 & $45 \mathrm{a}$ & 3 & $3 \mathrm{a}$ & 1 \\
\hline \multicolumn{12}{|c|}{1992} \\
\hline Control & 8 & $14 \mathrm{a}^{2}$ & 4 & $11 \mathrm{a}$ & 4 & $25 \mathrm{a}^{2}$ & 5 & $80 \mathrm{~b}$ & 9 & $1 \mathrm{c}$ & $<1$ \\
\hline Disc-90 & 24 & $23 \mathrm{a}$ & 3 & $4 b$ & I & $26 a$ & 3 & $106 a$ & 3 & $10 \mathrm{~b}$ & 2 \\
\hline Annual & 8 & $21 \mathrm{a}$ & 4 & $\mathrm{lb}$ & $<1$ & $22 \mathrm{a}$ & 4 & $96 a b$ & 8 & $24 a$ & 7 \\
\hline \multicolumn{12}{|c|}{1993 and 1994} \\
\hline Control & 16 & $2 b$ & 1 & $3^{3}$ & 1 & $6^{4}$ & 2 & $15 b^{2}$ & 3 & $0 \mathrm{c}$ & \\
\hline Disc-90 & 32 & $7 \mathrm{a}$ & 2 & 2 & $<1$ & 9 & 2 & $29 a$ & 3 & $4 b$ & 1 \\
\hline Disc-90,92 & 16 & $7 \mathrm{a}$ & 2 & 1 & $<1$ & 8 & 2 & $25 \mathrm{a}$ & 3 & $10 \mathrm{~b}$ & 2 \\
\hline Annual & 16 & $5 \mathrm{a}$ & 2 & $<1$ & $<1$ & 5 & 2 & $20 \mathrm{ab}$ & 2 & $21 \mathrm{a}$ & 3 \\
\hline \multicolumn{12}{|c|}{1995} \\
\hline Control & 8 & $<1^{3}$ & $<1$ & $5 a^{2}$ & 1 & $5 a^{2}$ & 1 & $23 \mathrm{a}$ & 4 & $<1 \mathrm{c}$ & $<1$ \\
\hline Disc-90 & 8 & 1 & $<1$ & $2 b$ & 1 & $3 b$ & 1 & $38 \mathrm{a}$ & 8 & $2 c$ & 1 \\
\hline Disc-94 & 8 & 1 & $<1$ & $<1 \mathrm{c}$ & $<1$ & $1 b$ & $<1$ & $13 b$ & 2 & $<1 \mathrm{c}$ & $<1$ \\
\hline Disc-90,94 & 8 & 1 & 1 & Obc & & $\mathrm{lb}$ & 1 & $19 a$ & 2 & $5 b c$ & 3 \\
\hline Disc-90,92,94 & 8 & 1 & 1 & $<\mathrm{lbc}$ & $<1$ & $\mathrm{lb}$ & 1 & $20 \mathrm{a}$ & 5 & $13 \mathrm{ab}$ & 6 \\
\hline Annual & 8 & 1 & $<1$ & $<\mathrm{lbc}$ & $<1$ & $\mathrm{lb}$ & $<\mathrm{I}$ & $19 a$ & 4 & $21 \mathrm{a}$ & 7 \\
\hline
\end{tabular}

${ }^{1}$ Means followed by the same letter are not significantly (P> 0.05) different based on Tukey's HSD. Analyses were for arcsin transformed means; means reported in the table are not transformed.

${ }^{2}$ Significant $(\mathrm{P}<0.05)$ difference between soil series

${ }^{3}$ Significant $(\mathrm{P}<0.05)$ soil series $\mathrm{x}$ treatment interaction.

${ }^{4}$ Significant $(\mathrm{P}<0.05)$ treatment $\mathrm{x}$ sampling date interaction.

ported greater $(\mathrm{P} \leq 0.05)$ canopy cover $(6 \pm 2 \%)$ of preferred perennials on Delfina fine sandy loams than plots disced annually and plots disced in October 1990 and $1992(1 \pm<1 \%)$.

On all disced treatments, canopy cover of annual and perennial preferred species combined was lower $(\mathrm{P}<0.05)$ than controls or did not differ significantly $(\mathrm{P}>$ $0.05)$ from controls except in March 1991 and 1993. Canopy cover on disced plots exceeded $(\mathrm{P}<0.05)$ controls in March 1991. There was a significant ( $\mathrm{P}$ $=0.020$ ) sampling date $\mathrm{x}$ discing treatment interaction for annual and perennial preferred species combined in March 1993 and 1994. In March 1993, canopy cover of preferred annuals and perennials combined was greater $(\mathrm{P} \leq 0.05)$ on plots disced in $1990(15 \pm 2 \%)$ than on controls $(7 \pm 2 \%)$. Canopy cover did not differ significantly $(\mathrm{P}>0.05)$ from controls on plots disced in 1990 and 1992 $(12 \pm 4 \%)$ and annually disced plots

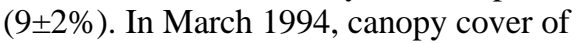
annual and perennial preferred species combined was lower $(\mathrm{P} \leq 0.05)$ on annually disced plots $(1 \pm 1 \%)$ than on controls or plots disced in $1990(3 \pm 1 \%)$ or plots disced in 1990 and $1992(4 \pm 1 \%)$.

With the exception of annually disced plots, herbaceous species eaten by deer but not preferred ("other species") had greater $(\mathrm{P}>0.05)$ canopy cover on discing treatments than on controls during March 1991-1994 (Table 2). Canopy cover of unpalatable plants was greater $(\mathrm{P}>0.05)$ on disced plots than on control plots, except in 1995 when canopy cover of unpalatable plants did not differ significantly $(\mathrm{P}>0.05)$ on plots disced one time only in October 1990 or October 1994. Annually disced plots contained the greatest $(\mathrm{P}<0.05)$ canopy cover of unpalatable plants.

\section{Discussion and Conclusions}

Production of herbaceous plants in semiarid environments is strongly governed by rainfall. Consequently, results of discing may be inconsistent from year to year because of variation in rainfall. For example, in this study, during March 1994 low rainfall (Fig. 1) may have inhibited disced plots from producing sufficient canopy cover of herbaceous plant species to detect differences among treatments.

I rejected the hypothesis that annual discing results in greater canopy cover of annual forbs preferred by deer than discing at less frequent intervals. Annual discing did not increase preferred annual forbs compared to plots disced only once, but consistently increased unpalatable forbs. Based on these results, annual discing is an undesirable management practice for increasing forbs eaten by white-tailed deer in the semiarid western Rio Grande Plains of Texas.

Increases in canopy cover of preferred annuals in March following discing in October were counterbalanced on the majority of sampling dates by reduced canopy cover of perennials preferred by white-tailed deer and I accepted the hypothesis that canopy cover of preferred perennials is reduced by frequent discing. Canopy cover of preferred perennials was also reduced by discing only once in 1990, and remained lower $(\mathrm{P}<0.05)$ than on controls throughout 


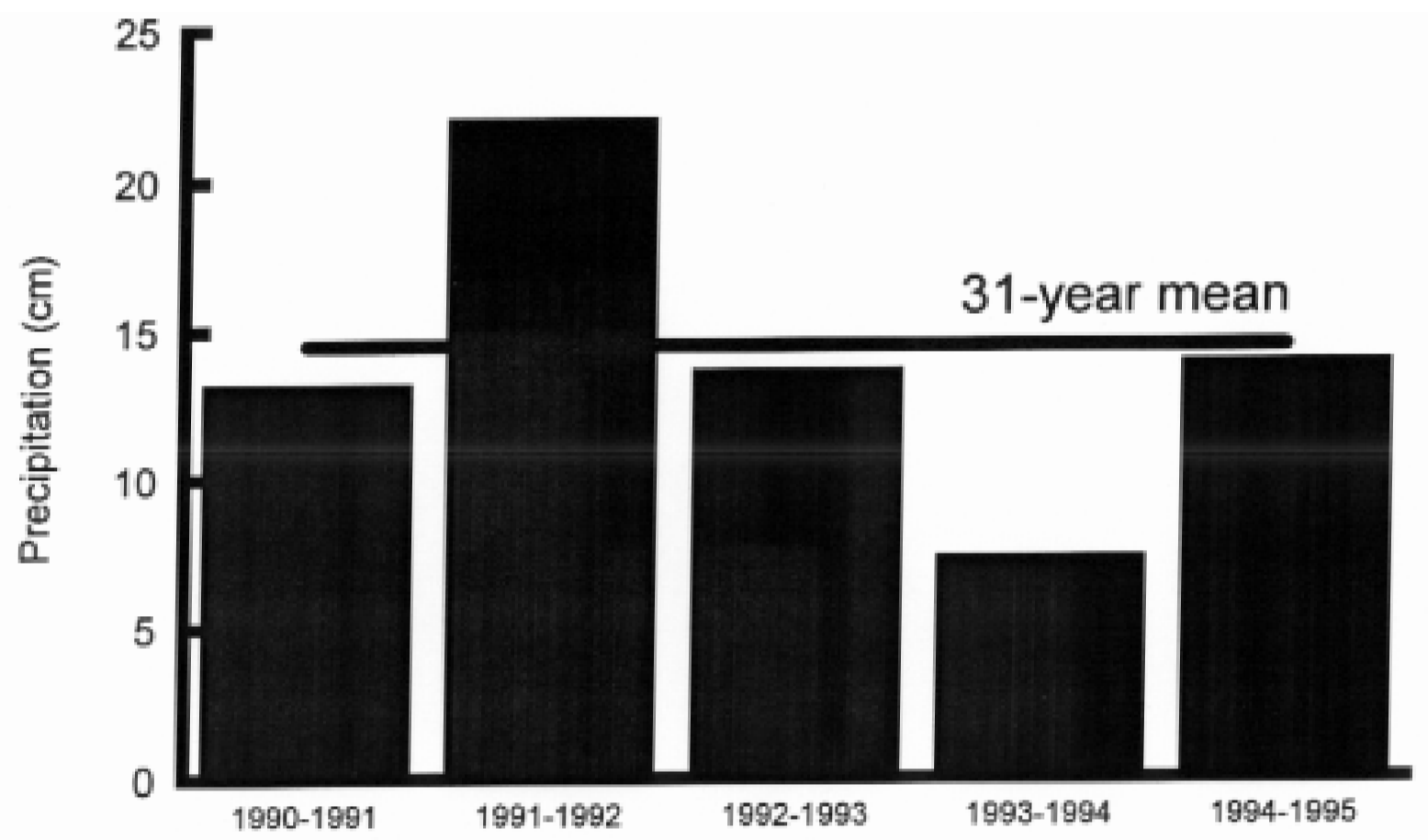

Fig. 1. Rainfall $(\mathrm{cm})$ during the 6-month period from discing in October to sampling in March 1990-1995 and mean rainfall during October-March 1931-1962 (Thompson et al. 1972), El Tecomate Ranch, Starr County, Tex.

the 5 years of study. Consequently, I also rejected the hypothesis that discing only once allows reestablishment of perennial forbs resulting in greater total canopy cover of annual and perennial forbs preferred by deer.

Soil disturbance by discing is not recommended as a habitat improvement practice in the semiarid western Rio Grande Plains of Texas if the objective of management is to increase canopy cover of forbs preferred by white-tailed deer. Although preferred annuals and moderately palatable species (other species eaten by deer) were increased in March during a 4-year period following a single discing event in October, increasing annual forbs at the expense of preferred perennial forbs is not a desirable management strategy. Perennial forbs constitute a more stable food source for deer on a year-long basis than do annual forbs (Chamrad et al. 1979). Additionally, perennial forbs generally constitute a much greater proportion of deer diets than annual forbs. On the Welder Wildlife Refuge in eastern south Texas, perennial forbs composed $17 \%$ of deer diets by volume compared to $40 \%$ for annual forbs. Virtually all treatments increased unpalatable forbs, which is another important undesirable result of discing.

\section{Literature Cited}

Arnold, L. A. and D. L. Drawe. 1979. Seasonal food habits of white-tailed deer in the South Texas Plains. J. Range Manage. 32:175-178.

Arnthórsdóttir, S. 1994. Colonization of experimental patches in mown grassland. Oikos 70:73-79.

Bozzo, J. A., S. L. Beasom, and T. E. Fulbright. 1992. Vegetation responses to 2 brush management practices in south Texas. J. Range Manage. 45:170-175.

Chamrad, A.D., B.E. Dahl, J.G. Kie, and D.L. Drawe. 1979. Deer food habits in south Texas-status, needs and role in resource management, p. 133-142. In: D.L. Drawe (ed.), Proceedings of the first Welder Wildlife Foundation symposium, Welder Wildlife Foundation Contr. B-7.

Cody, R.P. and J.K. Smith. 1991. Applied statistics and the SAS programming language, 3rd ed. North Holland, N Y.

Connell, J. H. 1978. Diversity in tropical rain forests and coral reefs. Sci. 199:1302-1310.

DeYoung, C. A. 1985. Accuracy of helicopter surveys of deer in south Texas. Wildl. Soc. Bull. 13:145-149.

Everitt, J. H. and D. L. Drawe. 1974. Spring food habits of white-tailed deer in the South Texas Plains. J. Range Manage. 27:15-19.

Glenn, S. M. and S. L. Collins. 1992. Effects of scale and disturbance on rates of immigration and extinction of species in prairies. Oikos 63:273-280.
Hehman, M. W. 1995. Use of warm-season food plots by white-tailed deer. M. S. Thesis, Texas A\&M University-Kingsville, Kingsville, Tex.

Jones, P. D., J. R. Sweeny, and T. Ivey. 1993. Effects of six discing regimes on quail foods in fallow fields. Proc. Annu. Conf. Southeast. Assoc. Fish and Wildl. Agencies 47:239-250.

Landers, J. L. and B. S. Mueller. 1986. Bobwhite quail management: A habitat approach. Misc. Pub. No. 6, Tall Timbers Res. Sta., Tallahassee, Fla.

Nurdin and T. E. Fulbright. 1988. Disking improved rangeland to increase wildlife food plants. Tex. J. Agr. and Natur. Resour. 2:32-34.

SAS Institute, Inc. 1988. SAS user's guide: statistics. SAS Inst. Inc, Cary, N.C.

Scifres, C. J. 1980. Brush management. Texas A\&M Univ. Press, College Station.

Thompson, C. M., R. R. Sanders, and D. Williams. 1972. Soil survey of Starr County, Texas. USDA., Soil Conserv. Serv., U. S. Govern. Printing Office, Washington, D. C.

Webb, W. M. and F. S. Guthery. 1983. Response of wildlife food plants to spring disking of mesquite rangeland in northwest Texas. J. Range Manage. 36:351-353. 